\title{
Electrochemical impedance and spectroscopy study of the EDC/NHS activation of the carboxyl groups on poly(e-caprolactone)/poly(m-anthranilic acid) nanofibers
}

\author{
Z. Guler ${ }^{1}$, A. S. Sarac ${ }^{1,2,3^{*}}$ \\ ${ }^{1}$ Department of Nanoscience and Nanoengineering, Maslak, Istanbul Technical University, 34469 Istanbul, Turkey \\ ${ }^{2}$ Department of Chemistry, Istanbul Technical University, Maslak, 34469 Istanbul, Turkey \\ ${ }^{3}$ Department of Polymer Science and Technology, Istanbul Technical University, Maslak, 34469 Istanbul, Turkey
}

Received 2 Juy 2015; accepted in revised form 2 September 2015

\begin{abstract}
Electrochemical impedance spectroscopy (EIS) and spectroscopy was applied to investigate the surface activation of carboxyl group (-COOH) containing nanofibers by the reaction of 1-ethyl-3-(dimethyl-aminopropyl) carbodiimide hydrochloride (EDC)/N-hydroxyl succinimide (NHS) in different concentrations. Poly(E-caprolactone)/poly(m-anthranilic acid) (PCL/P3ANA) nanofibers were fabricated by electrospinning and were activated with 5/0.5, 0.5/5, 5/5 and 50/50 mM of EDC/NHS. The surface activation was investigated by Attenuated Total Reflectance Fourier transform infrared spectroscopy (FTIR-ATR) and activation yield was estimated. Albumin was immobilized after surface activation and the amount of covalently immobilized protein was determined by bicinchoninic acid (BCA) assay. Morphology and composition of albumin immobilized nanofibers were characterized by Scanning Electron Microscopy/Energy-Dispersive X-ray Spectroscopy (SEM/EDX) and Atomic force microscope (AFM). EIS measurements indicated that nanofibers become resistant after albumin immobilization. The obtained data revealed that the highest amount of albumin bound to nanofibers activated with $50 / 50 \mathrm{mM}$ of EDC/NHS which was found to be the optimum concentration for the activation of PCL/P3ANA nanofibers.
\end{abstract}

Keywords: nanomaterials, covalent immobilization, electrochemical impedance spectroscopy (EIS), poly(m-anthranilic acid)

\section{Introduction}

Using nanostructured materials as supports for biomolecule immobilization have recently attract great interest considering their extremely high surface area to volume ratio [1]. Among these nanostructured materials, electrospun nanofibers stand out as the better alternative for immobilization of biomolecules due to the higher loading capacity and porosity compared to polymer films [2,3].

Polymeric nanofibers allow further optimization of properties such as electrical conductivity [4] to meet different requirements in various applications. In the case of conductive polymer containing nano- fibers, modification of a surface with a biomolecule can be detected by electrochemical impedance spectroscopy (EIS) [5, 6]. There other methods such as X-ray photoelectron spectroscopy (XPS), Thermal gravimetric analysis (TGA), Scanning electron microscopy (SEM) etc. can be used to investigate the surface modification [7], however EIS is a very sensitive method for the analysis of the interfacial properties such as resistance and capacitance of a surface by using very small amplitude sinusoidal voltage signals without significantly disturbing the properties being measured. Therefore, EIS is a sensitive, easy and cost effective method which allows

\footnotetext{
${ }^{*}$ Corresponding author, e-mail: sarac@itu.edu.tr

(c) BME-PT
} 
reuse of samples after EIS measurements. Poly(manthranilic acid) (P3ANA) is a very convenient conductive polymer for immobilization of biomolecules covalently due to the presence of carboxylic acid group $-\mathrm{COOH}$ on the main polyaniline backbone [8].

Covalent immobilization of the biomolecules by using reactive groups has been recognized as an attractive strategy since it provides the control of the immobilization of biological probes on the surface [9]. Covalent immobilization of biomolecules onto a $-\mathrm{COOH}$ group containing surface consists of preparation of a succinimidyl ester (-COOSuc)-terminated surface and its reaction with an amino $\left(-\mathrm{NH}_{2}\right)$ group on the biomolecule. This reaction is referred as surface 'activation' which is conducted by reacting a surface bearing carboxyl end groups with N-hydroxysuccinimide (NHS), in the presence of carbodiimide such as 1-ethyl-3-(dimethyl-aminopropyl) carbodiimide hydrochloride (EDC) [10]. EDC/NHS activation of carboxylic acids has been widely applied to various kinds of substrates of polymers [11], silicon [9], nanotubes [12] or nanoparticles [13, 14]. In these studies, the concentrations of EDC and NHS strongly vary in a wide range (from $\mathrm{M}$ to the $\mathrm{mM}$ range) from one study to another [15-17]. Voicu et al. [15], used 0.1 M NHS and 0.4 M EDC in order to activate silicon surface. In another study, equal amounts of EDC and NHS (100 mM) were used for activation of carboxylic acid terminated self-assembled monolayers [18]. Zander et al. [19] activated the surface of plasma-treated PCL nanofibers by using approximately $25 \mathrm{mM}$ EDC and $43 \mathrm{mM}$ NHS. Electrospun collagen or gelatin nanofibers were activated by $30 \mathrm{mM}$ EDC and $6 \mathrm{mM}$ of NHS [20]. Based on the EDC/NHS concentrations used in the literature, for the activation of carboxyl groups of PCL/P3ANA nanofibers, it was decided to use equal amounts of EDC/NHS (EDC/NHS $=5 / 5 \mathrm{mM}$ and $\mathrm{EDC} / \mathrm{NHS}=50 / 50 \mathrm{mM}$ ), excess amount of EDC over NHS $(\mathrm{EDC} / \mathrm{NHS}=5 / 0.5 \mathrm{mM})$ and excess amount of NHS over EDC (EDC/NHS $=0.5 / 5 \mathrm{mM})$. These concentrations were selected since very large concentrations of EDC or NHS result the formation of the byproducts at the surface which can prevent the formation of -COOSuc surface and affect the success of the surface activation. In the case of EDC and NHS concentrations are very low, then the surface activation reaction remains incomplete [7]. Although the EDC/NHS activation has been widely used, the details of EDC/NHS activation of carboxyl groups of a semiconducting nanofiber and of the following amidation of NHS-ester for protein immobilization have not been reported. This study aims to investigate the optimum EDC/NHS concentration for surface activation of PCL/P3ANA nanofibers by spectroscopy and electrochemical impedance spectroscopy.

Poly( $\varepsilon$-caprolactone)/poly(m-anthranilic acid) nanofibers were fabricated by electrospinning. Figure 1 represents the chemical structure of PCL/P3ANA and shows the interaction between partial positive charges of amine groups in P3ANA [21, 22] and partially negative charges in PCL backbone [23]. The activation of carboxyl groups on the surface of PCL/ P3ANA nanofibers were performed with different concentrations of EDC and NHS. Due to its low price and availability in large amounts, albumin was selected as model protein and covalently immobilized to activated nanofibers. The success of activation procedure and the amount of immobilized albumin were investigated by FTIR-ATR and the surface activation yield was estimated. The amount of covalently immobilized protein was determined by bicinchoninic acid assay. Morphology and composition of nanofibers before and after albumin immobilization were analyzed by AFM, (SEM)/(EDX). EIS analysis and equivalent circuit modeling was performed to observe the immobilized albumin depending on the EDC/NHS concentrations used in activation. The nanofibers become resistive due to albumin immobilization. The obtained data revealed that electrochemical impedance spectroscopy can be used for investigation of surface modification with biomolecule immobilization by the determina-

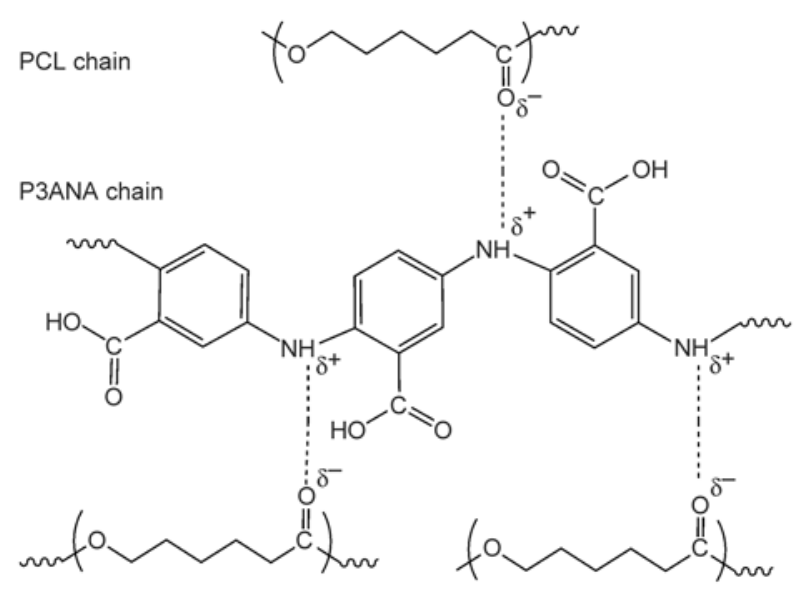

Figure 1. Schematic representation of the chemical structure of PCL/P3ANA 
tion and quantification of the optimum and effective concentration for the activation of carboxyl group bearing polymeric nanofibers.

\section{Experimental}

\subsection{Materials}

Poly( $\varepsilon$-caprolactone) (440744) $\left(M_{\mathrm{W}}=80000 \mathrm{~g} / \mathrm{mol}\right)$, 3-aminobenzoic acid (m-anthranilic acid) (127671), albumin $\left(M_{\mathrm{w}} \sim 66 \mathrm{kDa}\right)$ (A2153), $N$-(3-dimethylaminopropyl)- $N$ '-ethylcarbodiimide hydrochloride (EDC), $N$-hydroxysuccinimide (NHS), 2-morpholinoethane sulfonic acid (MES, low moisture content, $\geq 99$ ) and the bicinchoninic acid (BCA) Protein Quantitation Kit were purchased from Sigma Aldrich (St Louis, MO, USA). Phosphate buffer saline (PBS) was obtained from Gibco (Carlsbad, CA). Dimethyl formamide (DMF Analytical Grade) (103034) and Tetrahydrofurane (THF Analytical Grade) (109731) were supplied from Merck (Darmstadt, Germany). Poly(m-anthranilic acid) (P3ANA) was synthesized according to our previous study [8]. Briefly, 3aminobenzoic acid $(0.043 \mathrm{~mol})$ has been dissolved in $90 \mathrm{~mL}$ of $0.5 \mathrm{M} \mathrm{NaOH}$. Equal mole of ammonium persulfate in water $(30 \mathrm{~mL})$ has been added drop wise to this solution and the mixture was stirred at room temperature for $24 \mathrm{~h}$. The precipitated polymer has been collected by filtration, washed with 1.2 $\mathrm{M} \mathrm{HCl}$ and water until the filtrate became colourless and dried in vacuum at $60^{\circ} \mathrm{C}$ for two days. This polymer has been recovered in $70 \%$ yield as a brown powder. All of these chemicals were analytical grade and used as received.

\subsection{Fabrication of PCL/P3ANA nanofibers by electrospinning}

$0.125 \mathrm{~g}$ of poly(m-anthranilic acid) were dissolved in $5 \mathrm{~mL}$ THF and DMF mixture $(1 / 1 \mathrm{v} / \mathrm{v})$ containing $0.5 \mathrm{~g}$ poly( $\varepsilon$-caprolactone). The obtained polymer blend was stirred for $3 \mathrm{~h}$ at room temperature to obtain homogeneous solution for optimum electrospinning conditions.

Electrospinning solution was placed into a syringe needle (outer diameter of $0.7 \mathrm{~mm}$ ) which was connected to a high-voltage direct current (DC) power supply (ES 30 Model Gamma High Voltage Inc., Florida, USA). PCL/P3ANA solution was horizontally electrospun onto aluminum foil at $15 \mathrm{kV}$ driving voltage with a collection distance of $15 \mathrm{~cm}$. The flow rate of the solution was $1 \mathrm{~mL} / \mathrm{h}$ and controlled by a syringe pump (NE-500 Model, New Era Pump
Systems, Inc. New York, USA). For reproducible electrochemical measurements, nanofibers were also collected onto ITO-PET (NV Innovative Sputtering Technology, Zulte, Belgium, PET 175 lm, Coating ITO-60) substrate with dimensions of $0.5 \times 2.5 \mathrm{~mm}$, for $5 \mathrm{~min}$.

\subsection{Surface activation and covalent immobilization of albumin onto the PCL/P3ANA nanofiber mats}

In order to activate the $-\mathrm{COOH}$ groups available on the surface of the nanofiber mat, the appropriate concentrations $(5 / 0.5,0.5 / 5,5 / 5$ and $50 / 50 \mathrm{mM})$ of EDC and NHS solutions were prepared with cold water. In order to investigate the influence of EDC and NHS concentrations during activation of carboxyl $-\mathrm{COOH}$ groups in nanofibers, PCL/P3ANA nanofiber mats on ITO-PET substrates were treated by shaken gently with $5 \mathrm{~mL}$ of the EDC/NHS solutions for $2 \mathrm{~h}$ at room temperature [24]. Activated mats were then washed twice with water. Activated mats were treated with $1 \mathrm{~mL}$ of albumin dissolved in MES buffer ( $\mathrm{pH}$ 5.7) with the concentration of $2 \mathrm{mg} / \mathrm{mL}$. Nanofiber mats were incubated with albumin for $2 \mathrm{~h}$ at $+4{ }^{\circ} \mathrm{C}$, being shaken gently. Finally, mats were taken out, washed twice again with water and dried for characterization. Initial albumin solutions as well as the residual solutions of each consecutive washing step were collected for further characterization.

\subsection{Spectroscopic and morphological quantification of protein amount on the nanofiber mats}

The activation of carboxylic acid groups on PCL/ P3ANA nanofibers and the gradual change in the amount of immobilized protein depending on the EDC and NHS concentrations in the activation procedure was determined by FTIR-ATR spectrophotometer (Spectrum One, with a universal ATR attachment with a diamond and a ZnSe crystal) (Perkin Elmer, Massachusetts, USA), SEM/EDX (QUANTA 400 F) (FEI, Oregon, USA), AFM (Nanosurf EasyScan2) and BCA protein assay. The surface activation yield were estimated by calculation of the FTIR peak ratios of the formed succinimidyl ester and $\mathrm{O}-\mathrm{H}$ stretching of carboxylic acid group by using Beer-Lambert law. All FTIR-ATR spectra were collected with 12 scans in the $600-4000 \mathrm{~cm}^{-1}$ spectral region at $4 \mathrm{~cm}^{-1}$ resolution. SEM/EDX analyses were performed before and after albumin immobi- 
lization, with $10 \mathrm{kV}$ accelerating voltage after nanofiber mats were coated with gold by Ion Sputter Metal Coating Device (MCM-100 Model). The average nanofiber diameters were determined using Image $\mathrm{J}$ by randomly measuring the diameters of 20 individual fibers shown in SEM images with $1 \mu \mathrm{m}$ magnification. The influence of EDC and NHS concentrations on the structure and composition of the albumin immobilized PCL/P3ANA nanofibers were analyzed by detection of elemental concentrations for nitrogen and oxygen with EDX. The distribution of immobilized albumin on the surface of nanofiber mats was examined by EDX-mapping. The amount of immobilized albumin on the activated nanofiber mats was determined by BCA protein assay by subjecting the initial and residual solutions from albumin immobilization. As a control, albumin immobilization was carried out on nonactivated PCL/P3ANA nanofibers under the same experimental conditions. The total protein content in each sample was calculated by comparing the means of absorption values with a standard curve of bovine serum dilutions (between 0 and $2 \mathrm{mg} / \mathrm{mL}$ ). The samples were incubated with BCA working solution at $37^{\circ} \mathrm{C}$ for 30 minutes and the absorbance was followed at $562 \mathrm{~nm}$ by UV-Vis spectrophotometer (Lambda 45) (Perkin Elmer, Massachusetts, USA) [25]. AFM images of PCL/P3ANA and albumin immobilized nanofibers after activation with $5 / 0.5,0.5 / 5,5 / 5$ and $50 / 50 \mathrm{mM}$ of EDC and NHS, were taken in non-contact mode using $\mathrm{Al}$ coated high resonance frequency silicon tips (Nanosensors NCRL tips, $40 \mu \mathrm{m}$ width, $225 \mu \mathrm{m}$ length). Rootmean-square (RMS) roughness values of nanofibers
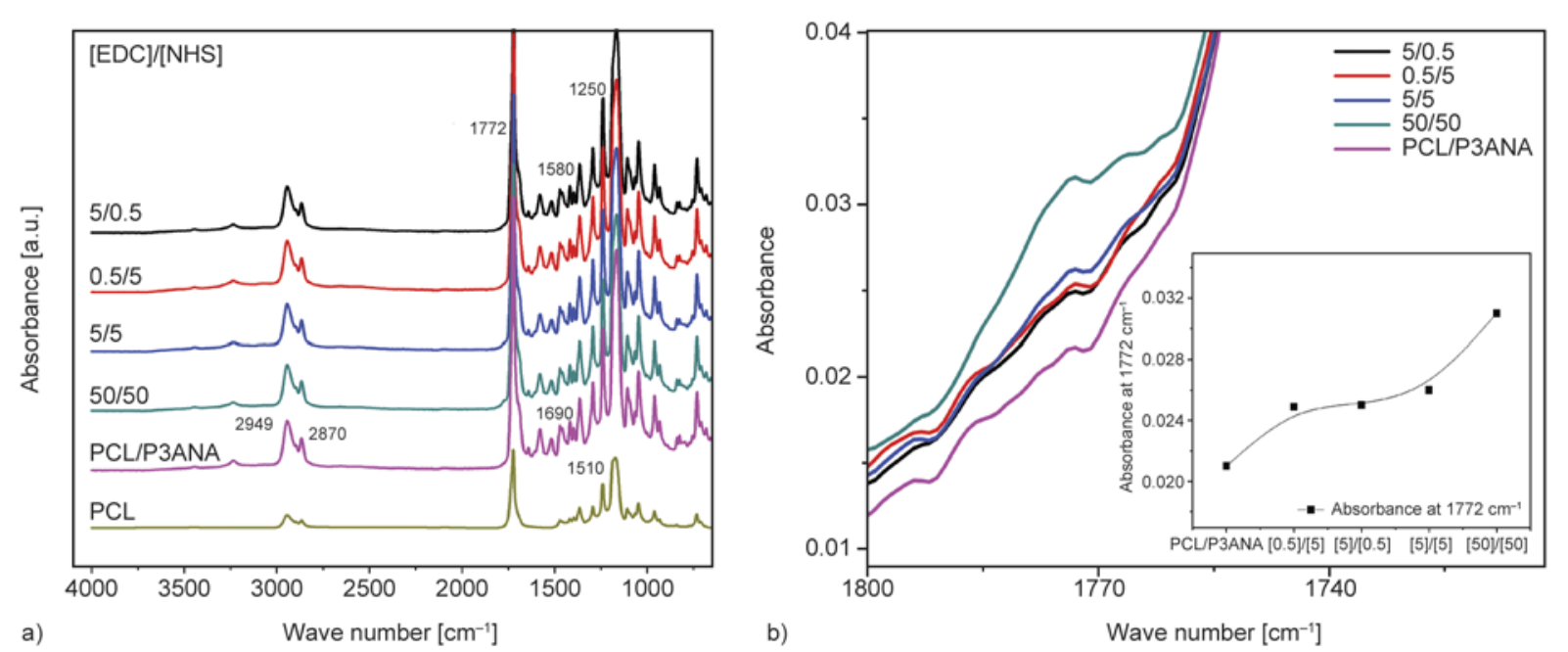

Figure 2. FTIR-ATR spectra of PCL, PCL/P3ANA and PCL/P3ANA nanofibers activated with EDC/NHS mixtures of various concentrations (a), succinimidyl ester absorbance (b) and the increase in absorbance (b inlet) after activation were calculated via Easy Scan 2 Software ${ }^{\mathrm{TM}}$ (version 3.0.2.4) by selecting raw data.

\subsection{Electrochemical impedance spectroscopic measurements of albumin immobilized nanofibers}

The effect of the concentrations of the EDC and NHS reactants on the activation reaction and on the amount of immobilized protein was investigated by Electrochemical Impedance Spectroscopy (EIS). EIS measurements were performed in PBS $(0.1 \mathrm{M}$, pH 7.4) using potentiostat 2263 Electrochemical Analyser (Princeton Applied Research, Tennessee, USA) with frequency range between $0.01 \mathrm{~Hz}$ and $100 \mathrm{kHz}$ and AC voltage of $10 \mathrm{mV}$. Three-electrode system, consisting of nanofiber mats after albumin immobilization as working electrode, platinum wire as counter electrode, and silver wire as pseudo reference electrode, was used. All measurements were repeated three times for confirmation. The measured impedance spectra were analyzed in terms of electrical equivalent circuits using the analysis program ZSimpWin V.3.10 (Princeton Applied Research, Tennessee, USA).

\section{Results and discussion}

\subsection{FTIR-ATR characterization of activated PCL/P3ANA nanofibers}

FTIR-ATR spectra of PCL/P3ANA nanofibers were obtained after activation procedure in order to reveal the influence of NHS and EDC concentrations (Figure 2). P3ANA in the PCL/P3ANA nanofibers displays the peaks at $2615,1690,1580$ and $1510 \mathrm{~cm}^{-1}$ which were attributed to $\mathrm{O}-\mathrm{H}$ stretching, $\mathrm{C}=\mathrm{O}$ 
stretching, $\mathrm{C}=\mathrm{C}$ stretching and $\mathrm{N}-\mathrm{H}$ stretching, respectively. The peaks at 1250 and $1070 \mathrm{~cm}^{-1}$ were attributed to $\mathrm{C}-\mathrm{N}$ stretching $[8,26]$. The carboxyl groups on P3ANA provide active sites for albumin binding through forming succinimidyl ester (-COOSuc) by reacting with NHS, in the presence of EDC [7]. The attachment of a succinimidyl ester termination to PCL/P3ANA nanofibers can be evidenced by the triplet in the spectral range of the $\mathrm{C}=\mathrm{O}$ stretching vibrations. The activation can be observed in some spectra by a shoulder or an asymmetry of the $1772 \mathrm{~cm}^{-1}$ peak ascribed to the contribution of the $\mathrm{C}=\mathrm{O}$ stretching mode [9]. The Figure $2 b$ shows the $\mathrm{C}=\mathrm{O}$ stretching vibrations of $\mathrm{PCL} /$ P3ANA nanofibers activated with different concentrations of EDC and NHS. When comparing the succinimidyl ester absorbance at $1772 \mathrm{~cm}^{-1}$ shown in Figure $2 b$ (inlet), at low concentrations $(0.5 \mathrm{mM}$ or $5 \mathrm{mM}$ ) of EDC and NHS, the activation reaction was incomplete. Compare to lower concentrations the activation was more successful when $\mathrm{EDC}=\mathrm{NHS}=$ $50 \mathrm{mM}$, since the peak absorbance at $1772 \mathrm{~cm}^{-1}$ was increased when the activation was performed by $50 / 50 \mathrm{mM}$ of EDC/NHS (Figure $2 \mathrm{~b}$ inlet).

The surface activation yield (Figure 3 ) was estimated by calculation of FTIR peak ratios of the formed succinimidyl ester and $\mathrm{O}-\mathrm{H}$ stretching of carboxylic acid group by using Beer-Lambert law. The relative percentages of surface species can be derived from their corresponding absorption bands by means of the Beer-Lambert law $(A=\varepsilon b c)$, where $A$ is the absorbance, $\varepsilon$ the extinction coefficient, $c$ the concentration and $b$ is the length of the sample layer which was the same for all nanofiber mats. For calculation, the peaks at 1772 and $2615 \mathrm{~cm}^{-1}$ were used for succinimidyl ester and $\mathrm{O}-\mathrm{H}$ stretching of carboxylic acid, respectively. Due to high absorbance of peak at $1772 \mathrm{~cm}^{-1}$, absorbance of peak at $2615 \mathrm{~cm}^{-1}$ was measured in an enlarged spectrum of 2000$2750 \mathrm{~cm}^{-1}$ region. To estimate the reaction yield, peak height was measured to represent the absorbance $(A)$ and the linear relationship among the individual extinction coefficients of succinimidyl ester and acid groups was 1:2 [14]. Activation yield for each PCL/ P3ANA nanofibers activated with different amounts of EDC and NHS, was calculated by Equation (1):

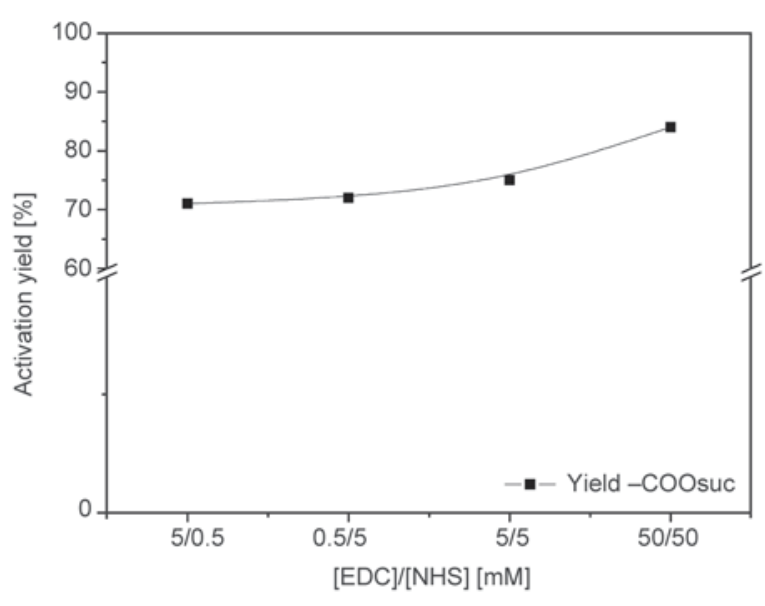

Figure 3. Surface activation yields of carboxylic acid groups on PCL/P3ANA nanofibers depending on the EDC/NHS concentrations used

The activation yield of carboxylic acid groups on PCL/P3ANA nanofibers activated with 5/0.5, 0.5/5, $5 / 5$ and $50 / 50 \mathrm{mM}$ of EDC and NHS was $71,72,73$ and $82 \%$.

Albumin immobilization was performed on the PCL/ P3ANA nanofibers after activation with different concentrations of EDC and NHS (Figure 4). When compared to the PCL/P3ANA nanofibers which were not treated with albumin solution and nanofibers activated with lower concentration $(0.5$ and $5 \mathrm{mg})$ of EDC and NHS, there were no significant changes on FTIR spectra. On the contrary, after albumin immobilization onto nanofibers activated with $50 / 50 \mathrm{mM}$ of EDC/NHS a broad peak was observed

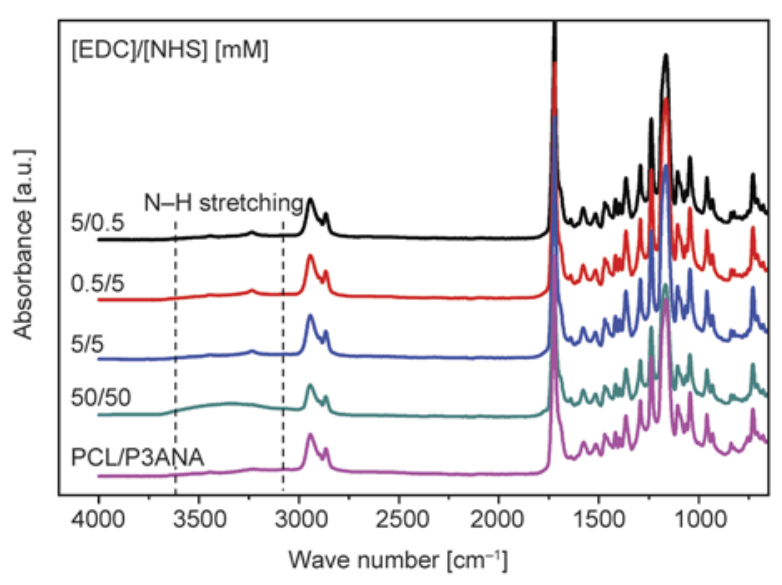

Figure 4. FTIR-ATR spectra of albumin immoblized PCL/ P3ANA nanofibers activated with EDC/NHS mixtures of various concentrations

$$
\text { yield }=\frac{A_{1772 / \varepsilon_{\text {succinimidyl ester }}}}{A_{1772 / \varepsilon_{\text {succinimidyl ester }}}+A_{2615 / \varepsilon_{\text {carboxylic acid }}}} \cdot 100 \%
$$


between 3000 and $3600 \mathrm{~cm}^{-1}$. The absorption in this region can be influenced by the contribution of water but in proteins the $\mathrm{N}-\mathrm{H}$ groups are generally in greater numbers than $\mathrm{O}-\mathrm{H}$ groups [27]. Also other albumin immobilized nanofibers showed no absorption at this region. The broad peak observed between 3000 and $3600 \mathrm{~cm}^{-1}$ region of FTIR spectrum of nanofibers activated with $50 / 50 \mathrm{mM}$ of EDC/NHS was attributed to the $\mathrm{N}-\mathrm{H}$ stretching vibration of albumin [28]. FTIR data (Figure 4) showed that PCL/P3ANA nanofibers were activated successfully only when $[\mathrm{EDC}]=[\mathrm{NHS}]=50 \mathrm{mM}$, therefore covalent binding of albumin was achieved on this nanofiber mat.

\subsection{Determination of immobilized protein amount by BCA assay}

In order to determine the amount of covalently bound albumin onto nanofibers, the amount of bound protein on both non-activated and activated nanofibers was determined by BCA protein assay. After each reaction step, the nanofiber mats were taken out and washed with PBS to remove any residual albumin on the nanofiber mats. They were then reintroduced into a fresh reaction medium, and the albumin amount was detected. Figure 5 shows the amount of covalently bound albumin onto nanofibers after each immobilization step. $2 \mathrm{mg} / \mathrm{mL}$ of albumin was incubated with non-activated PCL/P3ANA nanofibers (control) and PCL/P3ANA nanofibers which were activated by EDC/NHS at different concentrations. After incubation with albumin, albumin amount of the remaining solutions (cyan) were decreased. The difference between albumin amounts of the initial solutions $(2 \mathrm{mg} / \mathrm{mL})$ and solution obtained after

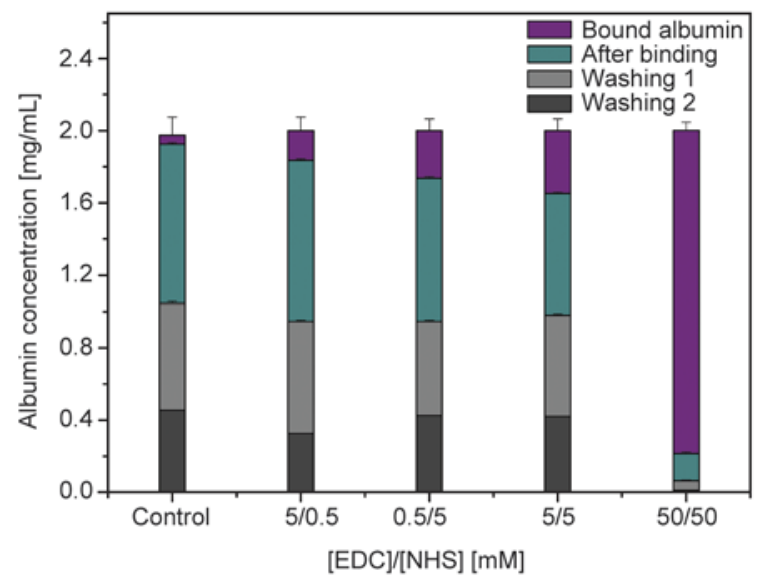

Figure 5. Amount of initial and residual albumin after each immobilization step binding step indicates that some of the protein is attached onto nanofibers. The highest amount of albumin $(\sim 1.85 \mathrm{mg})$ was attached onto nanofibers activated with $50 / 50 \mathrm{mM}$ of EDC/NHS. In control or other samples activated with lower concentrations of EDC and NHS, the residual albumin amounts in the solutions obtained after binding step were similar to each other. Two washing steps were applied in order to remove physically absorbed protein. The amounts of washed albumin from non-activated nanofibers or nanofibers activated with lower concentrations of EDC/NHS were higher compared to amount of albumin washed from PCL/PANA nanofibers activated by $50 / 50 \mathrm{mM}$ of EDC/NHS. This result indicates that the attachment was mostly physical on the nanofibers activated with lower concentrations of EDC/NHS. On the other hand, there was only $0.012 \mathrm{mg}$ protein in the solution remained from PCL/PANA nanofibers activated by EDC/NHS at $50 / 50 \mathrm{mM}$ concentration after two washing steps. In correlation with the FTIR-ATR data, albumin immobilization onto PCL/P3ANA nanofibers activated with $50 / 50 \mathrm{mM}$ of EDC/NHS was achieved with covalent binding, since the attached albumin cannot be removed with washing steps. The amount of albumin bound covalently (purple) was the highest $(\sim 1.78 \mathrm{mg} / \mathrm{mL})$, when nanofibers were activated with $50 / 50 \mathrm{mM}$ of EDC/NHS.

\subsection{Morphological and elemental composition analyses of activated PCL/P3ANA nanofibers}

The morphology (Figure 6,7) and elemental composition (Figure 8, Table 1) of albumin immobilized PCL/P3ANA nanofibers activated by different concentrations of EDC/NHS were investigated. The average diameter of albumin immobilized PCL/ P3ANA nanofibers activated with 5/0.5, 0.5/5, 5/5 and $50 / 50 \mathrm{mM}$ of EDC/NHS were determined as $86 \pm 19,75 \pm 16,87 \pm 21$ and $96 \pm 19 \mathrm{~nm}$, respectively. The average fiber diameter of PCL/P3ANA before activation was determined as $89 \pm 16 \mathrm{~nm}$. There is no significant change in diameter upon the binding of albumin onto PCL/P3ANA nanofibers activated with different concentration of EDC and NHS. AFM images of PCL/P3ANA and albumin immobilized nanofibers were represented in Figure 7. The surface of PCL/P3ANA nanofibers retained its topography after covalent immobilization of albumin indicating the EDC and/or NHS were not assembled or remained 
on the surface after washing steps [29]. PCL/P3ANA nanofibers have RMS roughness of $150.3 \mathrm{~nm}$. The surface roughness was slightly increased after albu- min immobilization. The RMS roughness values of albumin immobilized nanofibers which were preactivated with $5 / 0.5,0.5 / 5,5 / 5$ and $50 / 50 \mathrm{mM}$ of
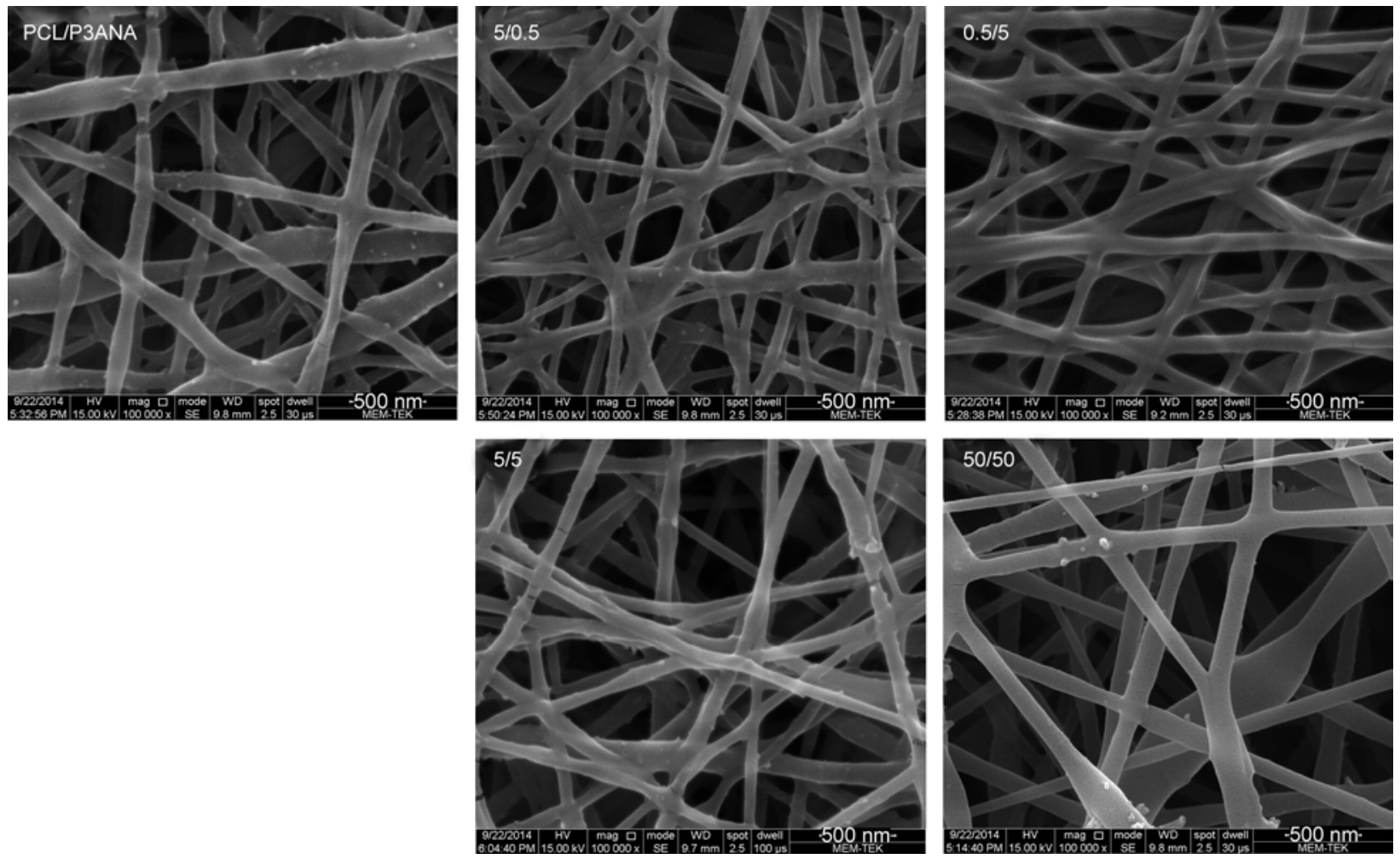

Figure 6. SEM images of PCL/P3ANA nanofibers and albumin immobilized PCL/P3ANA nanofibers activated with 5/0.5, $0.5 / 5,5 / 5$ and $50 / 50 \mathrm{mM}$ of EDC/NHS
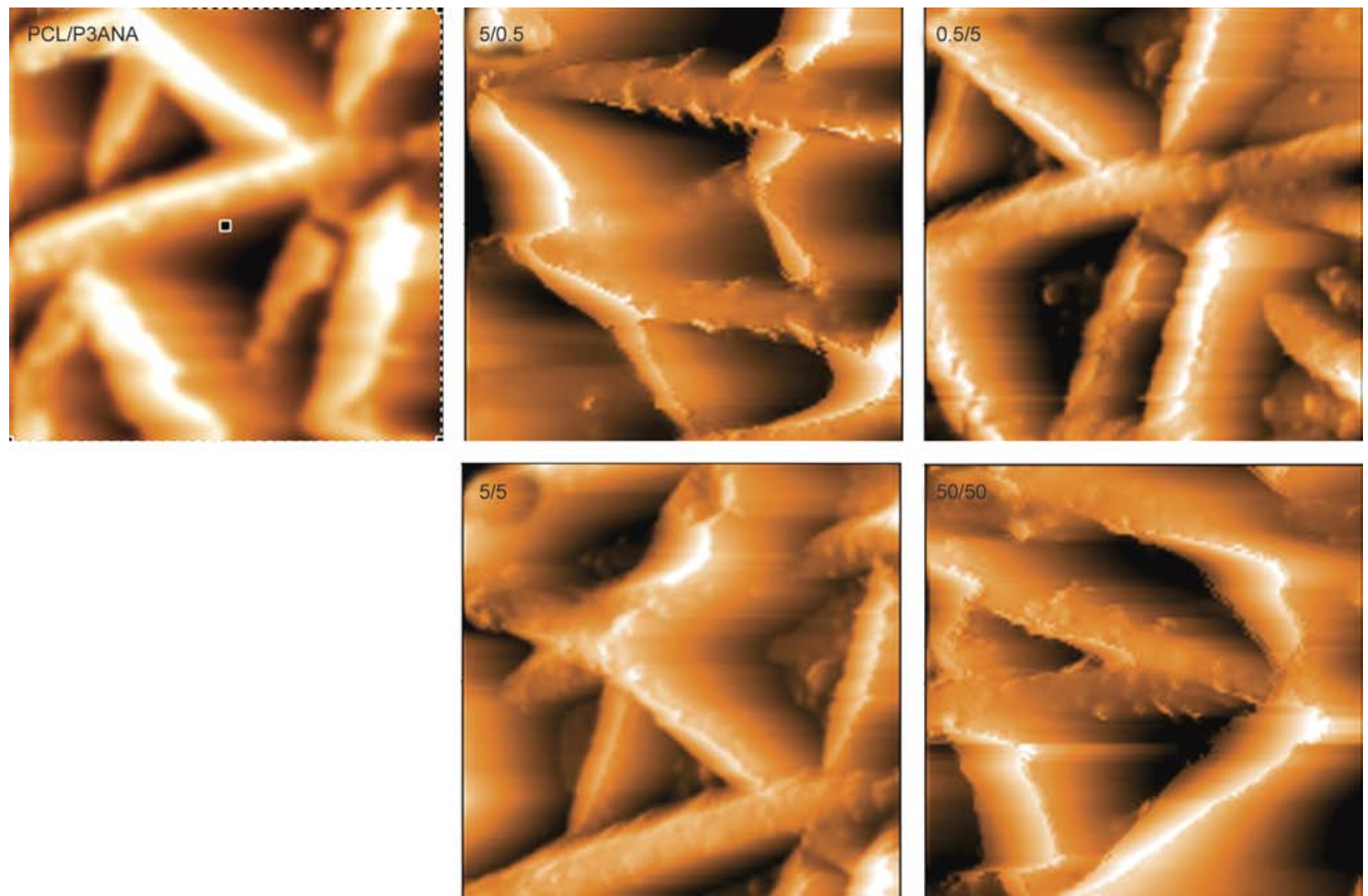

Figure 7. Topography AFM images $(6 \mu \mathrm{m} \times 6 \mu \mathrm{m})$ of PCL/P3ANA nanofibers and albumin immobilized PCL/P3ANA nanofibers activated with $5 / 0.5,0.5 / 5,5 / 5$ and $50 / 50 \mathrm{mM}$ of EDC/NHS 

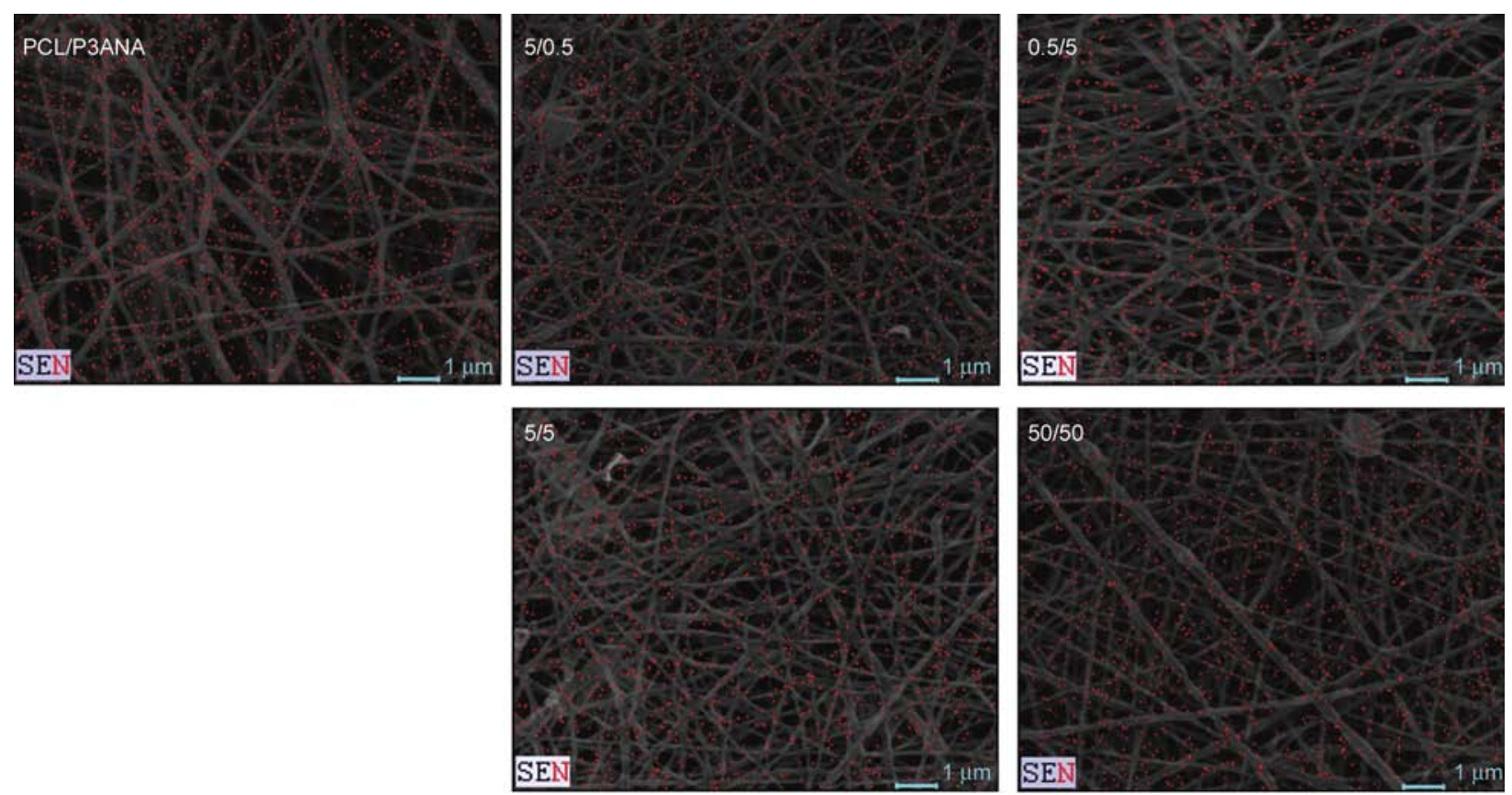

Figure 8. EDX-mapping of nitrogen (red) atoms on the surface of PCL/P3ANA nanofibers and albumin immobilized PCL/P3ANA nanofibers activated with 5/0.5, 0.5/5, 5/5 and 50/50 $\mathrm{mM}$ of EDC/NHS

Table 1. Elemental concentrations for nitrogen and oxygen atoms in PCL/P3ANA nanofibers and albumin immobilized nanofibers after activation with EDC/NHS

\begin{tabular}{|l|c|c|}
\hline \multirow{2}{*}{$\begin{array}{c}\text { Samples } \\
\text { [EDC]/[NHS] } \\
\text { [mM] }\end{array}$} & \multicolumn{2}{|c|}{$\begin{array}{c}\text { Elements } \\
\text { [wt\%] }\end{array}$} \\
\cline { 2 - 3 } & $\mathbf{N}$ & $\mathbf{O}$ \\
\hline PCL/P3ANA & 8.51 & 91.49 \\
\hline$[5] /[0.5]$ & 8.80 & 91.20 \\
\hline$[0.5] /[5]$ & 8.48 & 91.52 \\
\hline$[5] /[5]$ & 8.91 & 91.09 \\
\hline$[50] /[50]$ & 10.97 & 89.03 \\
\hline
\end{tabular}

EDC and NHS, were 176.2, 193.2, 208.9 and $226.69 \mathrm{~nm}$, respectively. This increase in roughness indicates the immobilization on albumin on the surface of activated PCL/P3ANA nanofibers [6, 30]. In correlation with FTIR-ATR, EDX and BCA, AFM images also indicates that the highest amount of albumin bound to nanofibers activated with $50 / 50 \mathrm{mM}$ of EDC/NHS.

EDX analyses were performed to confirm the presence of the albumin onto nanofibers. The structure and composition of the albumin immobilized nanofibers were analyzed by detection of elemental concentrations for nitrogen $(\mathrm{N})$ with EDX [31, 32]. Also, the distribution of immobilized albumin on the surface was investigated by EDX-mapping of PCL/ P3ANA nanofiber mats (Figure 8). P3ANA has N atoms in its backbone, as well as albumin. The distribution of nitrogen atoms on PCL/P3ANA nano- fiber mat seems to be random. It can be explained by the porous structure of nanofiber mat which affects the penetration depth of electrons during EDX analysis [33]. It is known that depending on the polymer chemical nature and porosity of mat, a loss of Xrays can be occurred [34]. Also, P3ANA and PCL blended in a weight ratio of $25 \% \mathrm{w} / \mathrm{w}$ between two polymers. Since both PCL and P3ANA contains oxygen atoms on their backbones, the amount of $\mathrm{O}$ atoms [wt $\%$ ] was 91.49 while $\mathrm{N}$ atom amounts [wt $\%$ ] was 8.81 on the surface of PCL/P3ANA nanofibers. The amount of $\mathrm{N}[\mathrm{wt} \%]$ on the surface of PCL/ P3ANA and of the nanofiber mats activated with $5 / 0.5,0.5 / 5$ and $5 / 05 \mathrm{mM}$ of EDC/NHS were approximately the same. However, when nanofibers were activated with increasing $(50 / 50 \mathrm{mM})$ amounts of EDC and NHS, the amount of N [wt\%] on the surface increased $(10.97 \mathrm{wt} \%$ ) which indicated that the $\mathrm{N}$ atoms were introduced to the structure of nanofibers through covalent binding of the albumin. The compositions of included atoms (nitrogen and oxygen) in the structure are given in Table 1. EDXmapping images of albumin immobilized nanofibers showed the distribution of the immobilized albumin (Figure 8). EDX-mapping images indicate that the distribution of the albumin on the surface of nanofibers is affected by the distribution of activated functional groups - $\mathrm{COOH}$ of P3ANA. SEM/EDX results have been complementary with FTIR-ATR, $\mathrm{BCA}$ protein assay and able to verify the covalent 
immobilization of albumin onto PCL/P3ANA nanofibers activated with higher and equal concentrations of EDC and NHS.

\subsection{Electrochemical impedance spectroscopy and equivalent circuit modeling}

Electrochemical impedance spectroscopy (EIS) measurements were performed on albumin immobilized PCL/P3ANA nanofibers on ITO-PET in order to understand the influence of NHS and EDC concentrations on the amount of bound albumin. The EIS data provide information about the nature of electrochemical process occurring at the electrode/electrolyte interface [35]. EIS data were obtained on PCL/ P3ANA and on albumin immobilized nanofibers which were activated with different concentrations of EDC and NHS. A significant difference in the impedance spectra was observed depending on the covalent immobilization of albumin onto nanofibers and the concentrations of the EDC and NHS used in activation. In Nyquist plot (Figure 9), albumin immobilized PCL/P3ANA nanofibers exhibited a semicircle while PCL/P3ANA nanofibers showed a linear behaviour. The diameter of the semicircle of Nyquist plot represents the charge-transfer resistance $\left(R_{\mathrm{ct}}\right)[8]$ and linear line with high-slope indicates capacitive behavior [36]. Nanofibers became resistive after treated with albumin and the chargetransfer resistance of the albumin immobilized nanofibers was increased. PCL/P3ANA nanofibers activated with $50 / 50 \mathrm{mM}$ of EDC/NHS had the largest diameter of the semicircle of the Nyquist plot indicated that the highest amount of albumin bound

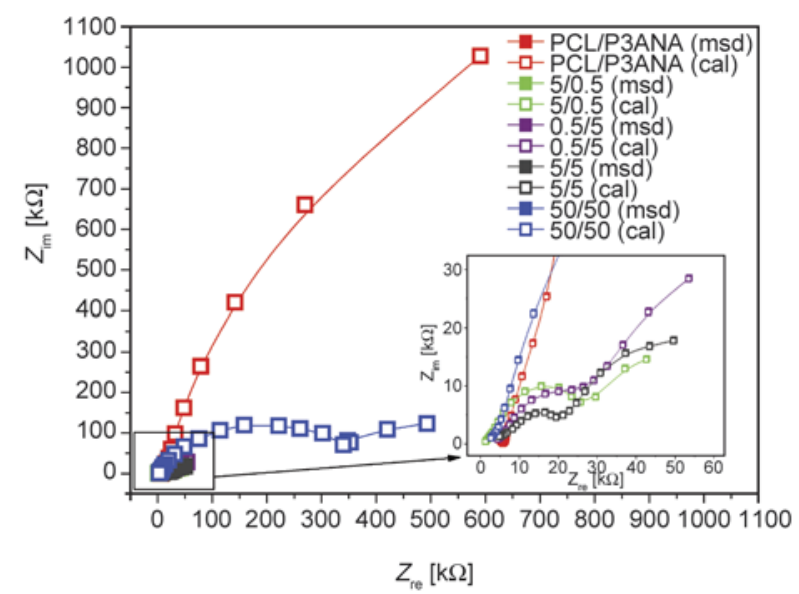

Figure 9. Measured (msd) and calculated (cal) Nyquist plots of PCL/P3ANA and albumin immobilized PCL/P3ANA nanofibers activated with $5 / 0.5$, $0.5 / 5,5 / 5$ and $50 / 50 \mathrm{mM}$ of EDC/NHS onto these nanofibers [37]. This result was in correlation with the data obtained from FTIR-ATR, SEM/EDX and BCA.

The measured impedance spectra were analyzed in terms of electrical equivalent circuits to evaluate the kinetics of the systems using the analysis program ZSimpWin. The circuits for PCL/P3ANA nanofibers and on albumin immobilized nanofibers which were activated with different concentrations of EDC and NHS, which describe the physical properties of the system and provide a good fit to the measured data with a reasonable number of circuit elements, were chosen. The calculated and measured data were fitted well together with the chosen equivalent circuits (Figure 9). The impedance spectra for nanofibers (PCL/P3ANA) described by the equivalent circuit of $R(C R)(Q R) W$ (Figure 10) in short hand. For albumin immobilized PCL/P3ANA, the equivalent circuit of $R(C R)(C R)(Q R) W$ were selected since there are additional electrical components (resistance and capacitance) arising from immobilized albumin. Table 2 represents the fitting parameters for the equivalent circuit elements by modeling of the impedance spectra.
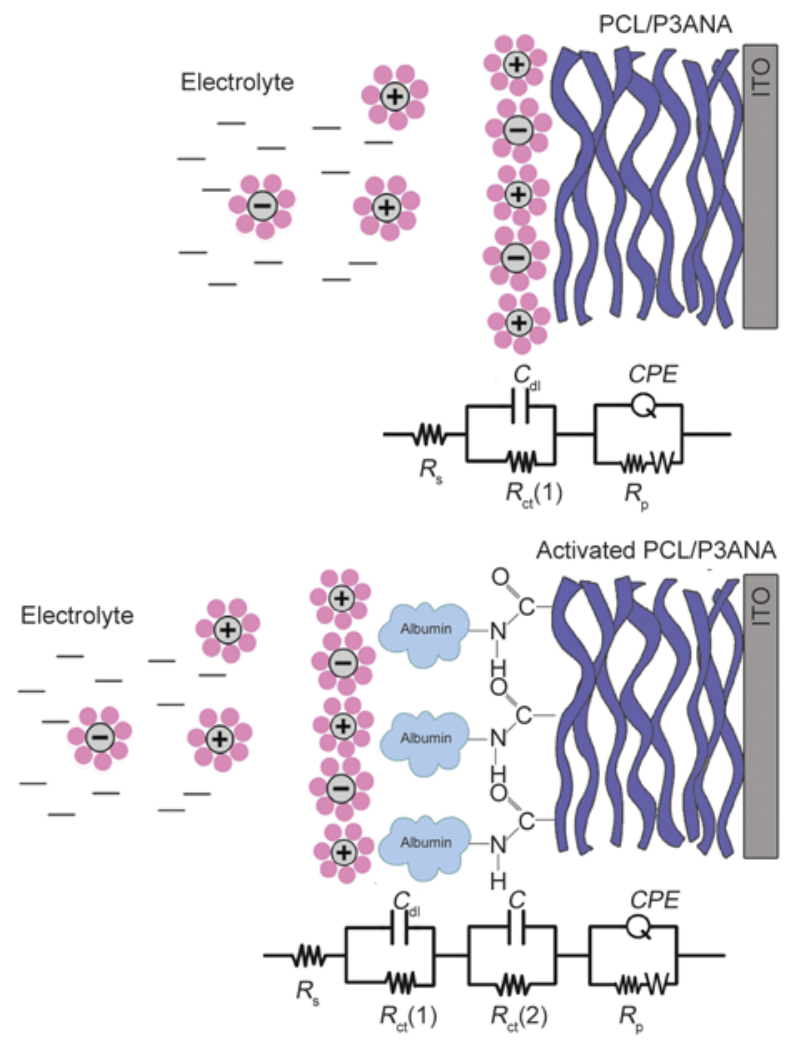

Figure 10. Equivalent circuits for the simulation of the EIS spectra of PCL/P3ANA (top) and albumin immobilized PCL/P3ANA nanofibers activated with EDC/NHS nanofibers (bottom) 
Table 2. Fitting values for the equivalent circuit elements by the simulation of the impedance spectra

\begin{tabular}{|c|c|c|c|c|c|c|c|c|c|c|}
\hline $\begin{array}{c}{[\mathrm{EDC}] /[\mathrm{NHS}]} \\
{[\mathrm{mM}]}\end{array}$ & $\begin{array}{c}R_{\mathrm{s}} \\
{[\Omega]}\end{array}$ & $\begin{array}{c}C_{\mathrm{dl}} \\
{[\mu \mathrm{F}]}\end{array}$ & $\begin{array}{c}R_{\mathrm{ct}}(\mathbf{1}) \\
{[\Omega]}\end{array}$ & $\begin{array}{c}C \\
{[\mu \mathrm{F}]} \\
\end{array}$ & $\begin{array}{c}R_{\mathrm{ct}}(2) \\
{[\mathrm{k} \Omega]}\end{array}$ & $\begin{array}{c}Q(\mathrm{CPE}) \cdot\left(10^{-7}\right) \\
{\left[\Omega^{-1}\right]}\end{array}$ & $\begin{array}{c}R_{\mathrm{p}} \\
{[\mathrm{k} \boldsymbol{\Omega}]} \\
\end{array}$ & $\begin{array}{c}W \cdot\left(10^{-5}\right) \\
{\left[\operatorname{Ssec}^{5} / \mathrm{cm}^{2}\right]}\end{array}$ & $n$ & $\begin{array}{l}\text { Chi-squared } \\
\text { error } \cdot\left(10^{-4}\right)\end{array}$ \\
\hline $\begin{array}{l}\text { PCL/P3ANA } \\
\text { R(CR)(QR)W }\end{array}$ & 2771 & 13.04 & 210 & - & - & 0.19 & 2.87 & 3.05 & 0.85 & 3.83 \\
\hline $\begin{array}{l}{[5] /[0.5]} \\
\mathrm{R}(\mathrm{CR})(\mathrm{CR})(\mathrm{QR}) \mathrm{W}\end{array}$ & 1108 & 0.08 & 1209 & 5.54 & 22.90 & 4.65 & 26.49 & 2.98 & 0.62 & 4.23 \\
\hline $\begin{array}{l}{[0.5] /[5]} \\
\mathrm{R}(\mathrm{CR})(\mathrm{CR})(\mathrm{QR}) \mathrm{W}\end{array}$ & 3403 & 0.09 & 1331 & 2.16 & 33.06 & 3.99 & 25.15 & 1.65 & 0.67 & 5.48 \\
\hline $\begin{array}{l}{[5] /[5]} \\
\mathrm{R}(\mathrm{CR})(\mathrm{CR})(\mathrm{QR}) \mathrm{W}\end{array}$ & 1143 & 0.08 & 4725 & 4.94 & 16.47 & 0.10 & 32.07 & 3.46 & 0.33 & 5.00 \\
\hline \begin{tabular}{|l|}
{$[50] /[50]$} \\
$\mathrm{R}(\mathrm{CR})(\mathrm{CR})(\mathrm{QR}) \mathrm{W}$
\end{tabular} & 974 & 0.06 & 52790 & 12.59 & 202.60 & 0.13 & 693.50 & 1.14 & 0.30 & 1.39 \\
\hline
\end{tabular}

$R_{\mathrm{S}}$, the first component of two circuits, represents the solution resistance of the electrolyte corresponds to the Ohmic resistance due to the presence of the electrolyte on the nanofiber and in solution [8] and of electrical contacts [38]. $R_{\mathrm{S}}$ values for PCL/ P3ANA nanofibers, albumin immobilized nanofibers activated with $5 / 0.5,0.5 / 5,5 / 5$ and $50 / 50 \mathrm{mM}$ of EDC and NHS were 2771, 1108, 3403, 1143 and $974 \Omega$, respectively. The $R_{\mathrm{S}}$ values correspond to the behavior of the electrolyte, filling pores of nanofibers [39]. The second resistance in both circuits represents the charge transfer resistance $\left(R_{\mathrm{ct}}\right)$ between the solution and the surface of the PCL/P3ANA nanofibers or albumin immobilized nanofiber electrode surface. The charge transfer resistance $R_{\mathrm{ct}}(1)$ of $210 \Omega$ of PCL/P3ANA nanofibers increased to $R_{\mathrm{ct}}(1)$ of $1209,1331,4725$ and $52790 \Omega$ after albumin immobilization onto nanofibers activated with $5 / 0.5,0.5 / 5,5 / 5$ and 50/50 mM of EDC/NHS, respectively. The increase in $R_{\mathrm{ct}}$ value is attributed to the formation of a new layer at the interface between solution and nanofibers [26]. First $C$ in the circuits was attributed to double layer capacitance $\left(C_{\mathrm{dl}}\right)$ arise from alignment of solvated counter ions along nanofiber surface. The electron transfer through electrode occurs by overcoming activation barrier, charge transfer resistance and solution resistance [40]. Double layer capacitance $\left(C_{\mathrm{dl}}\right)$ along the surface of PCL/P3ANA nanofibers was decreased after albumin immobilization. The decrease in $C_{\mathrm{dl}}$ is attributed to increase in thickness of electronic double layer depending on the albumin immobilization [26]. For albumin immobilized nanofibers, additional circuit elements of capacitance $(C)$ and resistance $(R)$ are connected in parallel to first ones in order to describe the capacitance and the charge transfer resistance between immobilized albumin molecules and PCL/P3ANA nanofibers, respectively. When PCL/P3ANA nanofibers were activated with
$50 / 50 \mathrm{mM}$ of EDC/NHS, the capacitance $(C)$ occurring at the interphase between immobilized albumin and nanofibers increased as well as the charge transfer resistance of $R_{\mathrm{ct}}(2)$. The difference between capacitance values of albumin immobilized nanofibers can be explained by the different interfacial structures, assuming different structures or sizes [41]. PCL/P3ANA nanofibers are porous electrodes and they provide large surface areas which forms interfaces between electrodes and electrolytes, resulting in high capacitances. The immobilization of albumin onto the surface of nanofibers induces higher $R_{\mathrm{ct}}$ values [42, 43]. The increase in $R_{\mathrm{ct}}$ values can be explained by the formation of a new layer at the interface between solution and nanofibers was formed after attachment of albumin onto surface [26]. The different interfacial structure between protein layer and nanofibers can cause higher $R_{\mathrm{ct}}$ values. Also, EIS measurements were performed in PBS buffer at $\mathrm{pH} 7.4$ where albumin become negatively charged [44]. In PBS buffer, the total positive charge concentration is greater than the total negative charge concentration [45]. After attachment of albumin on the surface, the negative charge on the surface of nanofibers was increased and this resulted in the alignment of positively charged solvated ions along the nanofiber surface and increase in $R_{\mathrm{ct}}$ values. Moreover, negatively charged ions can be repulsed by albumin on the surface and the transfer of positively charged and relatively big ions into positively charge nanofibers become challenging [24]. $Q$ represents the constant phase element (CPE) which was applied in the equivalent circuit for the simulation of the impedance data, since CPE takes into account the non-homogeneity of the conductance [8] and the electrode [38]. The impedance of a non-ideal electrode is defined by the formula $\left(Z_{\mathrm{CPE}}=\right.$ $\left.T_{\mathrm{CPE}}(j w)^{-\mathrm{n}}\right)$ where $T_{\mathrm{CPE}}$ and $n$ are frequency-independent constants; $w$ is the angular frequency [35], 
$n$ is a parameter describing the deviation from an ideal capacitor and arises from the slope of the $\log Z$ versus $\log f$ plot. The values for $n$ vary from 0 to 1 . $n=1$ belongs to an ideal capacitor, while $n=0$ and 0.5 denotes a resistance and Warburg behavior, respectively [46]. The $n$ value of PCL/P3ANA nanofibers was 0.85 and it is significantly reduced up to 0.30 with albumin immobilization. The values for $n=0$ indicates a resistance while $n=0.5$ denotes Warburg behavior. $W$ represents the Warburg impedance and it is attributed to the diffusion of counterions. Once the electron transfer begins, the electrode kinetics determined by Warburg impedance $(W)$ due to the mass transport [40]. $R_{\mathrm{p}}$ represents the pore resistances of the nanofiber layer (Ohmic resistances of the electrolyte in the pores) [47]. $R_{\mathrm{p}}$ values for PCL/P3ANA nanofibers were increased after albumin immobilization. These differences in $R_{\mathrm{p}}$ can be explained by the fact that covalent immobilization of albumin by EDC/NHS activation forms a different nanofiber mat structure [48]. The highest value of $693.50 \Omega$ of $R_{\mathrm{p}}$ was observed on nanofibers activated with $50 / 50 \mathrm{mM}$ of EDC and NHS. AFM images indicated that surface roughness increased after albumin immobilization onto nanofibers activated with $50 / 50 \mathrm{mM}$ of EDC and NHS, the increase in pore resistance value of PCL/P3ANA nanofibers $(50 / 50 \mathrm{mM}$ of EDC/NHS) can be related with the increase in surface roughness. EIS and equivalent circuit modeling indicated that $50 / 50 \mathrm{mM}$ of EDC/NHS were the most effective concentration on the activation of carboxylic acid groups on PCL/P3ANA nanofiber.

The activation of the carboxyl groups on the PCL/ P3ANA nanofibers can be achieved in several steps. The first step is the addition of the $\mathrm{OH}$ group of the carboxylic acid across one of the double bonds of the carbodiimide reactant, forming an O-acylurea adduct. Then, the surface O-acylurea can be transformed into succinimidyl ester (-COOSuc) product with a nucleophilic attack by NHS. Then, this product reacts with a primary amine and yield a peptide coupling through an amide bond (Figure 11). FTIRATR (Figure 2) analyses of the PCL/P3ANA nanofibers which were treated with different concentrations of EDC and NHS showed that, $50 / 50 \mathrm{mM}$ of EDC/NHS were the effective concentration to activate the nanofibers. Also, the success of covalent immobilization of the albumin is directly depending on the efficiency of the activation procedure. The subsequent analyses (FTIR-ATR, EDX, BCA and EIS) performed on albumin immobilized nanofibers indicated that the highest amount of albumin was bound onto nanofibers activated with $50 / 50 \mathrm{mM}$ of EDC/NHS. Figure 12 represents the relationship between the surface activation and albumin immobilization. The concentrations of nitrogen $(\mathrm{N})$ atoms at the surface and the charge transfer resistance of albumin immobilized nanofibers were increased as the activation of the nanofibers were achieved represented by the increase in the absorbance $\left(1772 \mathrm{~cm}^{-1}\right)$ of the succinimidyl ester. During the activation pro-

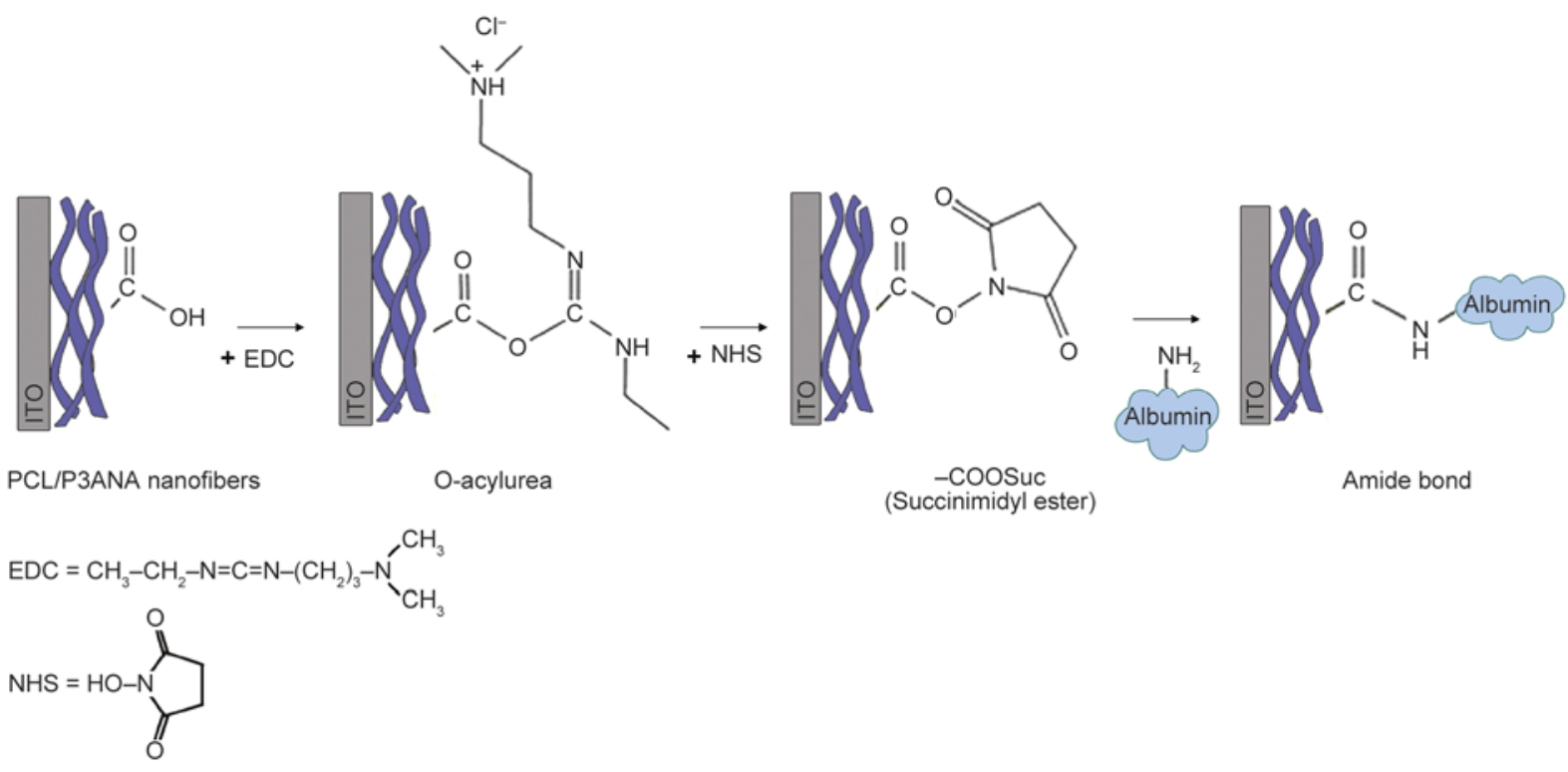

Figure 11. Schematic representation of covalent immobilization of protein through EDC/NHS activation 


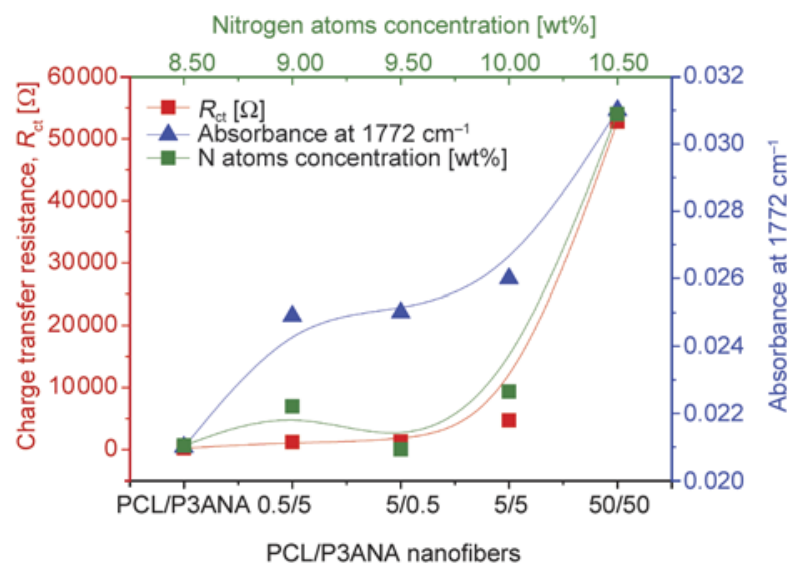

Figure 12. The relationship among charge transfer resitance $\left(R_{\mathrm{ct}}\right)$ from EIS, succinimidyl ester absorbance from FTIR-ATR and $\mathrm{N}$ atoms concentrations from EDX data of activated PCL/P3ANA nanofibers

cedure, the formation of the byproducts at the surface results a kinetic competition between different reactions [9]. In the case of EDC concentration is lower than NHS concentration $(0.5 / 5 \mathrm{mM})$, the formation of $\mathrm{O}$-acylurea become very slow resulting a slow succinimidyl ester formation. When EDC concentration is higher than NHS concentration $(5 / 0.5 \mathrm{mM}) \mathrm{O}$-acylurea formation become relatively fast however succinimidyl esters form very slow and byproducts of Anhydride and N-acylurea can be formed at the surface [49]. When NHS and EDC concentrations are equal to each other and both low $(5 / 5 \mathrm{mM})$ then slow kinetics for whole reaction are expected. On contrary, when the concentrations of both EDC and NHS increased to $50 \mathrm{mM}$, great balance between formation of O-acylurea and transformation of it into succinimidyl ester product can be obtained.

\section{Conclusions}

The nanofibers of poly( $\varepsilon$-caprolactone $) / \operatorname{poly}(\mathrm{m}$ anthranilic acid) (PCL/P3ANA) nanofibers were fabricated by electrospinning. Carboxyl groups on the surface of PCL/P3ANA nanofibers were activated by EDC and NHS in different concentrations $(5 / 0.5,0.5 / 5,5 / 5$ and 50/50 mM). Albumin was covalently immobilized onto activated nanofibers. The surface activation was investigated by FTIRATR and activation yield was calculated. The amount of immobilized albumin was investigated by BCA assay and elemental analyses (EDX) of nanofibers. AFM images showed that surface roughness of the nanofibers was increased after albumin immobilization. The amount of bound albumin was changed depending on the activation of the carboxyl groups of P3ANA. Elemental analyses and EDX-mapping of nitrogen atoms showed that the distribution of the albumin on the surface of nanofibers is affected by the distribution of activated $-\mathrm{COOH}$ groups of P3ANA. Electrochemical Impedance Spectroscopy (EIS) analysis and equivalent circuit modeling was performed to observe the immobilized albumin depending on the EDC/NHS concentrations used in activation. The nanofibers become resistive due to albumin immobilization and the higher charge transfer resistance was observed for the nanofibers activated with $50 / 50 \mathrm{mM}$ of EDC/NHS. This study showed that $50 / 50 \mathrm{mM}$ of EDC/NHS was the most effective concentration for the activation of PCL/ P3ANA nanofibers. This study indicated that Electrochemical Impedance Spectroscopic (EIS) analysis can be successfully applied for the determination of activation degree of covalent immobilization of proteins and enzymes onto polymeric substrates.

\section{Acknowledgements}

The authors express their thanks to Scientific and Technological Research Council of Turkey (TUBITAK) for the financial support on project 213M469.

\section{References}

[1] Ye P., Xu Z-K., Wu C., Innocent J., Seta P.: Nanofibrous poly(acrylonitrile-co-maleic acid) membranes functionalized with gelatin and chitosan for lipase immobilization. Biomaterials, 27, 4169-4176 (2006). DOI: $10.1016 /$ j.biomaterials.2006.03.027

[2] Marx S., Jose M. V., Andersen J. D., Russell A. J.: Electrospun gold nanofiber electrodes for biosensors. Biosensors and Bioelectronics, 26, 2981-2986 (2011). DOI: 10.1016/j.bios.2010.11.050

[3] Jung M., Kim S-U., Oh B-K., Choi J-W.: Immobilization of biomaterials on nanopatterned surface using nanoporous alumina for biodevices. Current Applied Physics, 9, e111-e114 (2009). DOI: $10.1016 /$ j.cap.2008.12.042

[4] Wang Z-G., Wan L-S., Liu Z-M., Huang X-J., Xu ZK.: Enzyme immobilization on electrospun polymer nanofibers: An overview. Journal of Molecular Catalysis B: Enzymatic, 56, 189-195 (2009). DOI: $10.1016 /$ j.molcatb.2008.05.005

[5] Llorens E., Armelin E., del Mar Pérez-Madrigal M., del Valle L. J., Alemán C., Puiggalí J.: Nanomembranes and nanofibers from biodegradable conducting polymers. Polymers, 5, 1115-1157 (2013). DOI: $10.3390 /$ polym5031115 
[6] Guler Z., Erkoc P., Sarac A. S.: Electrochemical impedance spectroscopic study of single-stranded DNAimmobilized electroactive polypyrrole-coated electrospun poly( $\varepsilon$-caprolactone) nanofibers. Materials Express, 5, 269-279 (2015).

DOI: $10.1166 / \operatorname{mex} .2015 .1249$

[7] Mohamad N. R., Marzuki N. H. C., Buang N. A., Huyop F., Wahab R. A.: An overview of technologies for immobilization of enzymes and surface analysis techniques for immobilized enzymes. Biotechnology and Biotechnological Equipment, 29, 205-220 (2015). DOI: 10.1080/13102818.2015.1008192

[8] Giray D., Balkan T., Dietzel B., Sarac A. S.: Electrochemical impedance study on nanofibers of poly(manthranilic acid)/polyacrylonitrile blends. European Polymer Journal, 49, 2645-2653 (2013).

DOI: $10.1016 /$ j.eurpolymj.2013.06.012

[9] Sam S., Touahir L., Andresa J. S., Allongue P., Chazalviel J. N., Gouget-Laemmel A. C. C., de Villeneuve C. H., Moraillon A., Ozanam F., Gabouze N., Djebbar S.: Semiquantitative study of the EDC/NHS activation of acid terminal groups at modified porous silicon surfaces. Langmuir, 26, 809-814 (2009).

DOI: $10.1021 / 1 \mathrm{a} 902220 \mathrm{a}$

[10] Staros J. V., Wright R. W., Swingle D. M.: Enhancement by $\mathrm{N}$-hydroxysulfosuccinimide of water-soluble carbodiimide-mediated coupling reactions. Analytical Biochemistry, 156, 220-222 (1986). DOI: 10.1016/0003-2697(86)90176-4

[11] Dai J., Baker G. L., Bruening M. L.: Use of porous membranes modified with polyelectrolyte multilayers as substrates for protein arrays with low nonspecific adsorption. Analytical Chemistry, 78, 135-140 (2006). DOI: $10.1021 / \mathrm{ac} 0513966$

[12] Wang Z-G., Wang Y., Xu H., Li G., Xu Z-K.: Carbon nanotube-filled nanofibrous membranes electrospun from poly(acrylonitrile-co-acrylic acid) for glucose biosensor. The Journal of Physical Chemistry C, 113, 2955-2960 (2009).

DOI: $10.1021 / \mathrm{jp} 807047 \mathrm{~s}$

[13] Dahoumane S. A., Nguyen M. N., Thorel A., Boudou J-P., Chehimi M. M., Mangeney C.: Protein-functionalized hairy diamond nanoparticles. Langmuir, 25, 9633-9638 (2009).

DOI: 10.1021/la9009509

[14] Wang C., Yan Q., Liu H-B., Zhou X-H., Xiao S-J.: Different EDC/NHS activation mechanisms between PAA and PMAA brushes and the following amidation reactions. Langmuir, 27, 12058-12068 (2011).

DOI: $10.1021 / 1 \mathrm{a} 202267 \mathrm{p}$

[15] Voicu R., Boukherroub R., Bartzoka V., Ward T., Wojtyk J. T. C., Wayner D. D. M.: Formation, characterization, and chemistry of undecanoic acid-terminated silicon surfaces: Patterning and immobilization of DNA. Langmuir, 20, 11713-11720 (2004).

DOI: $10.1021 / 1 \mathrm{a} 047886 \mathrm{v}$
[16] Wissink M. J. B., Beernink R., Pieper J. S., Poot A. A., Engbers G. H. M., Beugeling T., van Aken W. G., Feijen J.: Immobilization of heparin to EDC/NHS-crosslinked collagen. Characterization and in vitro evaluation. Biomaterials, 22, 151-163 (2001). DOI: 10.1016/S0142-9612(00)00164-2

[17] Yang Z., Wang J., Luo R., Maitz M. F., Jing F., Sun H., Huang N.: The covalent immobilization of heparin to pulsed-plasma polymeric allylamine films on $316 \mathrm{~L}$ stainless steel and the resulting effects on hemocompatibility. Biomaterials, 31, 2072-2083 (2010). DOI: 10.1016/j.biomaterials.2009.11.091

[18] Ducker R. E., Montague M. T., Leggett G. J.: A comparative investigation of methods for protein immobilization on self-assembled monolayers using glutaraldehyde, carbodiimide, and anhydride reagents. Biointerphases, 3, 59-65 (2008).

DOI: $10.1116 / 1.2976451$

[19] Zander N. E., Orlicki J. A., Rawlett A. M., Beebe Jr T. P.: Quantification of protein incorporated into electrospun polycaprolactone tissue engineering scaffolds. ACS Applied Materials and Interfaces, 4, 2074-2081 (2012). DOI: $10.1021 / \mathrm{am} 300045 \mathrm{y}$

[20] Casper C. L., Yang W., Farach-Carson M. C., Rabolt J. F.: Coating electrospun collagen and gelatin fibers with perlecan domain I for increased growth factor binding. Biomacromolecules, 8, 1116-1123 (2007). DOI: $10.1021 / \mathrm{bm} 061003 \mathrm{~s}$

[21] Benyoucef A., Huerta F., Vázquez J. L., Morallon E.: Synthesis and in situ FTIRS characterization of conducting polymers obtained from aminobenzoic acid isomers at platinum electrodes. European Polymer Journal, 41, 843-852 (2005).

DOI: $10.1016 / j$.eurpolymj.2004.10.047

[22] Vacareanu L., Catargiu A-M., Grigoras M.: An electrochemical study of two self-dopable water-soluble aniline derivatives: Electrochemical deposition of copolymers. Journal of Analytical Methods in Chemistry, 2012, 737013/1-737013/11(2012).

DOI: $10.1155 / 2012 / 737013$

[23] Khandanlou R., Ahmad M. B., Shameli K., Saki E., Kalantari K.: Studies on properties of rice straw/polymer nanocomposites based on polycaprolactone and $\mathrm{Fe}_{3} \mathrm{O}_{4}$ nanoparticles and evaluation of antibacterial activity. International Journal of Molecular Sciences, 15, 18466-18483 (2014).

DOI: $10.3390 /$ ijms 151018466

[24] Dagli U., Guler Z., Sarac A. S.: Covalent immobilization of tyrosinase on electrospun polyacrylonitrile/ polyurethane/poly( $m$-anthranilic acid $)$ nanofibers: An electrochemical impedance study. Polymer-Plastics Technology and Engineering, in press (2015). DOI: $\underline{10.1080 / 03602559.2015 .1010218}$ 
[25] Ficen S. Z., Guler Z., Mitina N., Finiuk N., Stoika R., Zaichenko A., Ceylan S. E.: Biophysical study of novel oligoelectrolyte-based nonviral gene delivery systems for mammalian cells. The Journal of Gene Medicine, 15, 193-204 (2013).

DOI: $10.1002 /$ jgm. 2710

[26] Sophia I. A., Gopu G., Vedhi C.: Synthesis and characterization of poly anthranilic acid metal nanocomposites. Open Journal of Synthesis Theory and Applications, 1, 1-8 (2012).

DOI: 10.4236/ojsta.2012.11001

[27] Grdadolnik J., Maréchal Y.: Bovine serum albumin observed by infrared spectrometry. I. Methodology, structural investigation, and water uptake. Biopolymers, 62, 40-53 (2001).

DOI: $10.1002 / 1097-0282(2001) 62: 1<40:: A I D-B I P 60>$ 3.0.CO;2-C

[28] Bouhekka A., Bürgi T.: In situ ATR-IR spectroscopy study of adsorbed protein: Visible light denaturation of bovine serum albumin on $\mathrm{TiO}_{2}$. Applied Surface Science, 261, 369-374 (2012).

DOI: $10.1016 /$ j.apsusc. 2012.08 .017

[29] Sargeant T. D., Rao M. S., Koh C. Y., Stupp S. I.: Covalent functionalization of NiTi surfaces with bioactive peptide amphiphile nanofibers. Biomaterials, 29, 10851098 (2008).

DOI: $10.1016 /$ j.biomaterials.2007.11.002

[30] Cho H-J., Perikamana S. K. M., Lee J-H., Lee J., Lee K-M., Shin C. S., Shin H.: Effective immobilization of BMP-2 mediated by polydopamine coating on biodegradable nanofibers for enhanced in vivo bone formation. ACS Applied Materials and Interfaces, 6, 11225-11235 (2014).

DOI: $10.1021 / \mathrm{am} 501391 \mathrm{z}$

[31] Meng J., Song. L., Zhong J., Wang C. Y., Kong H., Xu Z. Y., Xie S. S.: Comparison of adsorption behaviour for fibrinogen and albumin on single walled carbon nanotubes nonwoven. Solid State Phenomena, 121, 781-784 (2007).

DOI: 10.4028/www.scientific.net/SSP.121-123.781

[32] Timin A. S., Solomonov A. V., Musabirov I. I., Sergeev S. N., Ivanov S. P., Rumyantsev E. V., Goncharenko A.: Immobilization of bovine serum albumin onto porous poly(vinylpyrrolidone)-modified silicas. Industrial and Engineering Chemistry Research, 53, 13699-13710 (2014).

DOI: $10.1021 /$ ie $501915 \mathrm{f}$

[33] Rabiller-Baudry M., Gouttefangeas F., Le Lannic J., Rabiller P.: Coupling of SEM-EDX and FTIR-ATR to (quantitatively) investigate organic fouling on porous organic composite membranes. in 'Current microscopy contributions to advances in science and technology' (ed.: A. Méndez-Vilas) Formatex, Badajoz, 1066-1076 (2012).
[34] Otto T. N., Habicht W., Dinjus E., Zimmerman M.: Catalyst characterization with FESEM/EDX by the example of silver-catalyzed epoxidation of 1,3-butadiene. in 'Scanning electron microscopy' (ed.: Kazmiruk V.) InTech, Rijeka, 367-392 (2012). DOI: $10.5772 / 37952$

[35] Gu H., Su X. D., Loh K. P.: Electrochemical impedance sensing of DNA hybridization on conducting polymer film-modified diamond. The Journal of Physical Chemistry B, 109, 13611-13618 (2005). DOI: $10.1021 / j p 050625$ p

[36] Feng X., Chen N., Zhou J., Li Y., Huang Z., Zhang L., Ma Y., Wang L., Yan X.: Facile synthesis of shape-controlled graphene-polyaniline composites for high performance supercapacitor electrode materials. New Journal of Chemistry, 39, 2261-2268 (2015).

DOI: 10.1039/C4NJ01843E

[37] Rodríguez-Sevilla E., Ramírez-Silva M-T., RomeroRomo M., Ibarra-Escutia P., Palomar-Pardavé M.: Electrochemical quantification of the antioxidant capacity of medicinal plants using biosensors. Sensors, 14, 14423-14439 (2014). DOI: $10.3390 / \mathrm{s} 140814423$

[38] Zehani N., Dzyadevych S. V., Kherrat R., JaffrezicRenault N. J.: Sensitive impedimetric biosensor for direct detection of diazinon based on lipases. Frontiers in Chemistry, 2, 1-7 (2014). DOI: $10.3389 /$ fchem.2014.00044

[39] Radecka M., Wierzbicka M., Rekas M.: Photoelectrochemical cell studied by impedance spectroscopy. Physica B: Condensed Matter, 351, 121-128 (2004).

DOI: $10.1016 /$ j.physb.2004.05.020

[40] Park J-Y., Park S-M.: DNA hybridization sensors based on electrochemical impedance spectroscopy as a detection tool. Sensors, 9, 9513-9532 (2009). DOI: $10.3390 / \mathrm{s} 91209513$

[41] Kityakarn S., Pooarporn Y., Songsiriritthigul P., Worayingyong A., Robl S., Braun A. M., Wörner M.: (Photo) electrochemical characterization of nanoporous $\mathrm{TiO}_{2}$ and Ce-doped $\mathrm{TiO}_{2}$ sol-gel film electrodes. Electrochimica Acta, 83, 113-124 (2012). DOI: $10.1016 /$ j.electacta.2012.07.129

[42] Zainudin N., Hairul A. R. M., Yusoff M. M., Tan L. L., Chong K. F.: Impedimetric graphene-based biosensor for the detection of Escherichia coli DNA. Analytical Methods, 6, 7935-7941 (2014). DOI: $10.1039 / \mathrm{C} 4 \mathrm{AY} 01836 \mathrm{~B}$

[43] Chang B-Y., Park S-M.: Electrochemical impedance spectroscopy. Annual Review of Analytical Chemistry, 3, 207-229 (2010). DOI: 10.1146/annurev.anchem.012809.102211

[44] Tribet C., Porcar I., Bonnefont P. A., Audebert R.: Association between hydrophobically modified polyanions and negatively charged bovine serum albumin. The Journal of Physical Chemistry B, 102 1327-1333 (1998). DOI: $10.1021 / j p 973022$ p 
[45] Birner S., Uhl C., Bayer M., Vogl P.: Theoretical model for the detection of charged proteins with a silicon-on-insulator sensor. Journal of Physics: Conference Series, 107, 012002/1-012002/15 (2008). DOI: $10.1088 / 1742-6596 / 107 / 1 / 012002$

[46] Lu X., Dou H., Yuan C., Yang S., Hao L., Zhang F., Shen L., Zhang L., Zhang X.: Polypyrrole/carbon nanotube nanocomposite enhanced the electrochemical capacitance of flexible graphene film for supercapacitors. Journal of Power Sources, 197, 319-324 (2012). DOI: 10.1016/j.jpowsour.2011.08.112

[47] Panić V. V., Dekanski A. B., Mišković-Stanković V. B., Nikolić B. Ž.: The study of capacitance change during electrolyte penetration through carbon-supported hydrous ruthenium oxide prepared by the solgel procedure. Chemical and Biochemical Engineering Quarterly, 23, 23-30 (2009).
[48] Pauliukaite R., Ghica M. E., Fatibello-Filho O., Brett C. M. A.: Electrochemical impedance studies of chitosan-modified electrodes for application in electrochemical sensors and biosensors. Electrochimica Acta, 55, 6239-6247 (2010).

DOI: 10.1016/j.electacta.2009.09.055

[49] Douarche C., Cortès R., de Villeneuve H. C., Roser S. J., Braslau A.: DNA adsorption at functionalized Si/buffer interfaces studied by X-ray reflectivity. The Journal of Chemical Physics, 128, 225108/1-225108/15 (2008). DOI: $\underline{10.1063 / 1.2927256}$ 